\title{
The Role of Competency and Succession Program to Retain Millennial Healthcare Workers \\ Case Study in Indonesian Small Scale Maternity Hospital)
}

\author{
Mira Pratiwi, Sandra Dewi, and Hasyim
}

\section{ABSTRACT}

The turnover rates among millennial employees have become serious issue for many industries including healthcare industry. The negative economically outcome due to high turnover rate can vary from direct and indirect, tangible and intangible cost to the organization.

The cause of high turnover rate has been explained in many literatures, which includes leadership as one of the factors. Many studies have been underlining the importance of leadership style in lowering the number of turnover. Albeit some of leadership style may be proven to be effective in certain organization, the shift of millennial characteristic pressed other scholars to analyze if current theories of leadership style may sufficient and fitting to millennial. Therefore, there has been a gap in the literature between leadership style and leadership traits.

The purpose of this research is to study the relation between effective leadership traits for managing millennial and its' impact to lower millennial healthcare workers turnover intention. Teamwork is an important aspect in millennial setting; therefore, it is used as moderator to imply if teamwork may strengthen the relation between the two previous variables.

The study was held in a small-scale maternity hospital in Malang, Indonesia, with the population of 57 millennial employees. The results of this research effort may help to fill the gap in the literature about the relationship between leadership traits, teamwork, and employee's turnover for millennial in the workplace; and will hopefully help the organization to understand better the millennial motives to stay, and to bridge understanding between employer and employees.

Keywords: Leadership Traits, Turnover Intention, Teamwork, Millennial Employees, Healthcare Industry.

Submitted : February 7, 2021

Published : February 20, 2021

ISSN: 2507-1076

DOI: $10.24018 /$ ejbmr.2021.6.1.742

Mira Pratiwi *

Hospital Administration Magister Program, Esa Unggul University, Indonesia.

(e-mail: mirapratiwi@ gmail.com)

Sandra Dewi

Hospital Administration Magister Program, Esa Unggul University, Indonesia.

(e-mail: sandra@esaunggul.ac.id)

Hasyim

Hospital Administration Magister Program, Esa Unggul University, Indonesia.

(e-mail: hasyim.ahmad@esaunggul.ac.id)

*Corresponding Author

\section{INTRODUCTION}

\section{A. Literature Review}

Workforce turnover is a normal process within human resource department in many organizations including healthcare sector. However, the rise of turnover can become great concern due to the negative economically impact to the organizations themselves. The direct impact may include recruitment costs, temporary labor costs, employee's relocation costs, training costs, capitalization of salary leave costs, and induction fees. Indirect impact such as decreased productivity and morale, although cannot be felt directly but can be challenging for the operational functioning and routines of the organization. Additionally, the low morale of the remaining employees may cause further turnover [1].

Researches have estimated the required cost to recruit and train new employees is equal to $50 \%$ of the annual employees' salary due to the loss of productivity during the transition of workers. Based on these findings, many organizations consider the first 6 months of employees' salaries as investment costs [2].

Therefore, it is prudent for organizations to consider strategies on retaining the current employees. In addition, employee's retention will maintain good corporate relation for both between employees - organizations, as well as employees - customers.

\section{B. Relational Factors Affecting Turnover Intention}

Turnover intention is often described as the predictor of the actual turnover. Researches on turnover intention are expected to give feedback to organizations in maintaining their employees. Previous literatures mention factors such as: high salaries, bonuses, benefits, and career paths may tempt employees to stay within organizations; thus, some studies stated that those factors still cannot trigger the enthusiasm and motivation of employees to stay within organization, in particular their millennial employees. Accordingly, organizations need to take measurement and 
investment to maintain their employees in the form of providing training, leadership support, work processes innovation, and career path in order to reduce turnover intention [3].

Leadership behavior has been considered as one of the major contributing factors in reducing turnover intention [4]. When employees feel comfortable with their leaders, employees are more likely to stay within the company, and vice versa [5]. Leaders are expected to be able to create work activities to stimulate good collegial relationships among employees. A good collegial relationship is considered as an important factor for employees to maximize their productivity and efficiency, so as to reduce turnover intention significantly [6].

Beside leadership, teamwork is considered as major contributing factor to retain employees. Due to the bureaucratic system diminution in many organizations, the relationship between coworkers works horizontally instead of vertically, and naturally forced coworkers to work together as team more regularly than before [7]. Teamwork is proven to increase productivity, output quality, balanced quality for employees' personal and work life, even reducing turnover intention and conflict [8].

\section{Justification for the Current Study}

Today, the number of millennial employees dominates the total percentage of employees in the organization. In the next 5 years, millennial will dominate more than $60 \%$ of the workforce. Organizations face challenges such as: attracting and retaining millennial employees; manage employees with different generations background within workplace; and to manage workforce dynamics that will continue to change [9].

Several studies have found that $60 \%$ of millennial employees leave the workplace within three years. So, it is essential for leaders to understand how to cultivate a workplace environment that attracts millennial and influence them to stay long-term. Some literature states the importance of companies and organizations to adapt to millennial characteristic, work and life value, as well as work habit [10], [11]. Organizations that successfully adapt to globalization, new technologies, and horizontal leadership models can improve morale, reduce turnover, and increase sales and profits [12].

Many senior leaders cannot understand their millennial employees motivation; therefore leaders cannot comprehend why their leadership methods ineffective towards the millennial [3]. Experts realize that leaders must gain deeper understanding of the overall social-economic, political background of millennial. By recognizing the approach to facilitate millennial appropriately will support the leadership regeneration in an organization [13].

Some of millennial characteristic and motivation according to some literatures are as follow: solid leadership and teamwork, challenges at work, opportunity to collaborate, flexible and non-traditional working hours, supporting technology, and organizational culture [14], [15].

However, the lack of literatures on effective leadership traits for millennial may limit this research. Leadership theories that are widely used in various organizations such as transformational leadership, servant leadership, and ethical leadership have overlapping characteristics, and may not necessarily incorporate millennial generations motivation, values, and expectations [13].

Furthermore, leadership theories that have been circulating so far have focused on the characteristics of leadership styles. The definition of leadership has always evolved accordingly, hence researchers are welcome to research and explore further on leadership characteristics and attributes that continue to evolve along with the change of generational cohorts, and millennial in particular.

Therefore, this study seeks to address the mentioned literature gap, in particular to examine how health professional perceptions on leadership, teamwork, and turnover intention with its hypothesis as follow:

Hypothesis 1. Leadership has negative effect on turnover intention significantly.

Hypothesis 2. Teamwork has negative effect on turnover intention significantly.

Hypothesis 3. Teamwork moderates significantly the effect of leadership on turnover intention.

\section{METHOD}

\section{A. Setting}

This study was conducted at small-scale maternity hospital in Malang, Indonesia. The hospital has approximately 25 inpatient beds and offers a variety of specialty services including obstetric and gynecologist, pediatric, internist, fertility care, and dental care. This research takes place from April-May 2020.

\section{B. Sampling and Data Collection Procedures}

Data were obtained from millennial employees from all units and departments within the age of 18-30 years old by the time this research is conducted. The study sample included all staff in the above description. Survey data were collected between $25^{\text {th }}$ of April $-5^{\text {th }}$ of May 2020. The questionnaire was given to enumerator with attendee list to ensure most of the respondents participate in the survey. The enumerator would then collect the respondent individually or in a small group of 2 or 3 to fill the questionnaire. The enumerator was allowed to explain carefully the content of the questionnaire, and the respondents were free to ask the enumerator if needed. Respondents were asked to indicate their age, gender, education background, tenure, position, and the unit they assigned on. Nonetheless, the questionnaire is completely anonymous.

\section{Measures}

A survey was constructed using previously validated scales to access respondents' perceptions on leadership traits for millennial, teamwork, and turnover intention. Demographic data on age, gender, profession, position and tenure were also collected.

\section{Dependent Variables}

\section{Turnover intention}

A three-item turnover intention measure by Mobley [16] was used in this study, which are: (1) Thinking to quit, (2) Intent to search, (3) intent to quit. Items were rated on a Likert-type scale from 1 (strongly disagree) to 5 (strongly 
agree), with a middle option, Neither Agree Nor Disagree. The three negative context of turnover intention above have been reverse coded as it made intuitive sense that a low score on the corresponded to a higher intention to leave.

\section{E. Independent Variables}

\section{Leadership traits}

Leadership traits were measured using ten items that found to be ideal and effective for millennial generation [14]. The 10 items include: (1) informal contact, (2) guidance, (3) development of others, (4) absence of hierarchy, (5) empowering, (6) flexibility providing, (7) trust, (8) adaptability, (9) feedback providing, and (10) open for new ideas. Items were rated on a Likert-type scale from 1 (strongly disagree) to 5 (strongly agree), with a middle option, Neither Agree Nor Disagree.

\section{Teamwork}

Teamwork was measured by Civility, Respect, and Engagement in the Workforce (CREW). Osatuke et al. [17] founded this instrument in 2009. The instrument consists of 8 question that include items such as: (1) Respect, (2) Cooperation, (3) Conflict Resolution, (4) Coworker Personal Interest, (5) Coworker Reliability, (6) Antidiscrimination, (7) Value Differences, (8) Supervisor Diversity Acceptance. Items were rated on a Likert-type scale from 1 (strongly disagree) to 5 (strongly agree), with a middle option, Neither Agree Nor Disagree.

\section{F. Analysis}

The analysis was carried out using moderated regression analysis logistic binary using SPSS program. Product Moment Pearson Correlation was used to assess the validity of the questionnaire. Cronbach's $\alpha$ values were calculated to assess the reliability of the questionnaire for leadership traits, teamwork, and turnover intention variables.

\section{RESULT}

\section{A. Response Rate and Sample Characteristics}

57 out of 60 people responded to this survey, thus make the response rate of $95 \%$. Most study participants were female $(94,7 \%)$ nurses $(21,1 \%)$ with healthcare diploma and bachelor degree $(64,9 \%)$ had tenure of $0-2$ years $(63,2 \%)$, and within age group of 24-26 years old (50,9\%).

\section{B. Reliability and Validity Analysis}

The Cronbach's $\alpha$ value for leadership attribute was 0,90 , the teamwork scale was 0,86 , and turnover intention scale was 0,89 thus prove all indicators in all three variables > 0,60 to be reliable. The Pearson $r$ results are $>r$ table $(0,361)$ thus prove all indicators in all three variables to be valid (Table 1).

\section{Regression Model Test}

The feasibility of the regression model was tested using Hosmer and Lomeshow's Goodness of Fit Test. The criterion is if the value of sig. $>\alpha$. Table 2 shows that the value of $\operatorname{sig}(0.126)>\alpha(0.05)$. Therefore, the model can predict the value of observation well.
TABLE 1: DEMOGRAPHIC INFORMATION OF THE WHOLE SAMPLE (N=57)

\begin{tabular}{|c|c|c|c|}
\hline & & Frequency & Percent \\
\hline \multirow[t]{3}{*}{ Age } & $19-23$ & 18 & $31.6 \%$ \\
\hline & $24-26$ & 29 & $50.9 \%$ \\
\hline & $27-30$ & 10 & $17.5 \%$ \\
\hline \multirow[t]{2}{*}{ Gender } & Male & 3 & $5.3 \%$ \\
\hline & Female & 54 & $94.7 \%$ \\
\hline \multirow[t]{3}{*}{ Tenure } & $0-2$ years & 36 & $63.2 \%$ \\
\hline & 2-5 years & 13 & $22.8 \%$ \\
\hline & $>5-10$ years & 8 & $14 \%$ \\
\hline \multirow[t]{6}{*}{ Education } & $\begin{array}{c}\text { Highschool Diploma Non- } \\
\text { Healthcare }\end{array}$ & 12 & $21.1 \%$ \\
\hline & $\begin{array}{c}\text { Highschool Diploma in } \\
\text { Healthcare }\end{array}$ & 8 & $14 \%$ \\
\hline & $\begin{array}{c}\text { Associate Diploma in } \\
\text { Healthcare }\end{array}$ & 22 & $38.6 \%$ \\
\hline & $\begin{array}{c}\text { Public Health Bachelor } \\
\text { Graduate }\end{array}$ & 1 & $1.8 \%$ \\
\hline & $\begin{array}{c}\text { Midwifery Bachelor } \\
\text { Graduate }\end{array}$ & 10 & $17.5 \%$ \\
\hline & Nursing Bachelor Graduate & 4 & $7 \%$ \\
\hline \multirow[t]{5}{*}{ Position } & $\begin{array}{c}\text { Head of Medical Report } \\
\text { Unit }\end{array}$ & 1 & $1.8 \%$ \\
\hline & $\begin{array}{c}\text { Head of Medical Service } \\
\text { Unit }\end{array}$ & 2 & $3.5 \%$ \\
\hline & Head Of Infrastructure Unit & 1 & $1.8 \%$ \\
\hline & Head of Nutrition Unit & 1 & $1.8 \%$ \\
\hline & Executive Workers & 53 & $91.1 \%$ \\
\hline \multicolumn{4}{|c|}{ TABLE 2: REGRESSION MODEL TESTS } \\
\hline \multicolumn{4}{|c|}{ Hosmer and Lemeshow Test } \\
\hline Step & Chi-square $\quad \mathrm{df}$ & Sig. & \\
\hline 1 & 11.307 & .126 & \\
\hline
\end{tabular}

Source: SPSS Test Result (2020).

\section{Overall Model Test}

This test is used to assess the whole model by comparing the value of -2 Log Likelihood in block 0 with the value of 2 Log Likelihood in block 1. The overall test table for this study is declared fit if there is a good decrease of value of -2 Log Likelihood from block 0 to block 1 .

\begin{tabular}{ccc}
\multicolumn{3}{c}{ TABLE 3: OVERALL MODEL FIT TEST } \\
\hline \multirow{2}{*}{ Model } & $\begin{array}{c}\text {-2 Log } \\
\text { Likelihood } \\
\text { (block 0) }\end{array}$ & $\begin{array}{c}\text { Likelihood } \\
\text { (block 1) }\end{array}$ \\
\hline With Moderation & 78,580 & 70,889 \\
Without Moderation & 78,580 & 58,217 \\
\hline Source: SPSS Test Result (2020).
\end{tabular}

\section{E. Nagelkerke R-square}

The coefficient of determination is to determine the ability of independent variables representing the dependent variable. The closer the number is to 1 , the better the independent variable in representing dependent variables. The coefficient of determination is determined by Nagelkerke R-square value that can be seen in the following table:

TABLE 4: COEFFICIENT DETERMINATION

\begin{tabular}{cccc}
\hline & Block 1 & Block 2 & Block 3 \\
\hline Nagelkerke Rsquare & 0,169 & 0,239 & 0,402 \\
\hline Source: SPSS Test Result (2020).
\end{tabular}

\section{F. Hypothesis Test}

\section{Partial hypothesis test}

Partial hypothesis test is used to determine whether there is a partial influence of independent variables on the 
dependent variable. The criterion of this test is the value of sig. $\leq \alpha$. The results of partial hypothesis test can be seen on following table:

TABLE 5: PARTIAL HYPOTHESIS TEST

\begin{tabular}{|c|c|c|c|c|c|c|c|}
\hline \multicolumn{8}{|c|}{ Variables in the Equation } \\
\hline & & $\mathrm{B}$ & S.E. & Wald & $\mathrm{df}$ & Sig. & Ket \\
\hline \multirow{4}{*}{ Step $1^{\mathrm{a}}$} & $X$ & -3.687 & 1.781 & 4.288 & 1 & .038 & \multirow{4}{*}{$\begin{array}{c}\mathrm{H} 1 \\
\text { accepted } \\
\mathrm{H} 2 \\
\text { accepted } \\
\text { H3 } \\
\text { accepted }\end{array}$} \\
\hline & M & -4.560 & 2.232 & 4.174 & 1 & .041 & \\
\hline & XM & .125 & .058 & 4.579 & 1 & .032 & \\
\hline & $\begin{array}{c}\text { Consta } \\
\text { nt } \\
\text { a. V } \\
\end{array}$ & $\begin{array}{r}133.733 \\
\text { ariable(s) }\end{array}$ & 67.803 & 3.890 & M, & .049 & \\
\hline
\end{tabular}

The test results indicate the value of Sig. $<0.05$. This means that there is partially significant influence of leadership traits, teamwork, and the interaction of leadership traits and teamwork on turnover intention.

\section{Moderation hypothesis test}

The moderation test is used to analyze the outcome of moderating variable on the relations between independent variable and dependent variable. A test criterion is if the value of sig. $\leq \alpha$, the moderating variable is able to moderate the effect of the independent variable on the dependent variable.

The result produces sig. $(0.032)<\alpha(0.05)$. This means that teamwork moderates the influence of leadership traits on turnover intention.

However, the Positive B value shown in the table 8 indicates opposite interaction with the previous 2 variables. This result indicates that the interaction of leadership traits and teamwork weakens the effect of leadership traits to turnover intention. In short, this means that the interaction of leadership traits and teamwork increase turnover intention significantly.

\section{DISCUSSION}

The survey results supported all hypotheses. In Hypothesis 1, the direct relationships of leadership traits and turnover intention were found to be negatively significant.

$\mathrm{R}$-square value for leadership trait is 0,169 or $16,9 \%$. This means contribution factors of leadership traits on turnover intention is $16,9 \%$, while the remaining $83,1 \%$ contribution factors were not discussed in this study.

This finding is consistent with Wiley's statement (1993), which argues that contributing factors of voluntary turnover are as follow: lack of feedback and career development, job dissatisfaction, unmet job expectations, job stress, and social culture constraint.

Hypothesis test results suggest that leadership trait has significantly negative effect on turnover intention of millennial employees. These results are in accordance with previous studies by Abate et al. [18]; Asiedu et al. [19]; Smith \& Nichols [20]; and Wells \& Peachey [21].

The result of this study also illuminates several other contributing factors that can affect turnover intention. Nurcahyanto et al. [22] states that leadership has no significant effect on turnover intention, and employees' desire to leave an organization primarily based on personal motivation to become entrepreneurs. In addition, due to the majority of employees are women (94.7\%) contributing factors such as organizational barriers, personal factors, family pressures, and social and cultural restrictions influence the employees' decision to leave the organizations [23].

In hypothesis 2 , the direct relationships of teamwork and turnover intention were found to be negatively significant. These results are in accordance with previous studies by Zaheer et al. [1], Yuniasanti et al. [24], Nelsey \& Brownie [25], Rafferty et al. [26], Pinel \& Paulin [27], Leiter et al. [6].

Millennial generations are used to work as a team, and they are very open to collaborate with others at work. Therefore, they believe the importance of teamwork to increase their productivity and to build network [12], [15].

$\mathrm{R}$-square value for teamwork is 0,239 or $23,9 \%$. This means contribution factors of leadership traits on turnover intention is $23,9 \%$, while the remaining $76,1 \%$ contribution factors were not discussed in this study. This finding is consistent with Houghton et al [8] statements, which argues that beside leadership, teamwork is proven to increase productivity, output quality, better personal and work life quality, as well as to reduce turnover intention and conflict.

For hypothesis 3 , the contribution factors of leadership trait, teamwork, interaction between leadership trait and teamwork towards turnover intention is $40,2 \%$. Hypothesis test result of the interaction of leadership traits with teamwork on turnover intention produces a probability of $0.032<\alpha$. Therefore, teamwork moderates the influence of leadership traits on turnover intention.

However, the B value shows opposite interaction between leadership trait, teamwork, and interaction between leadership traits and teamwork on turnover intention. This indicates that the interaction of leadership trait and teamwork will further increase turnover intention.

Analyses of these findings are based on descriptive analysis and interviews with the hospital director and head of HR unit. The absence of gap between senior-juniors, supervisor-subordinate relationship may cause the leadership ineffectiveness within the organization and therefore further increase turnover intention. Due to the camaraderie and solidarity among workers, leaders may feel reluctant to supervise or reprimand subordinates. Consequently, subordinates feel the lack of guidance by superiors. In accordance with Schaeffer [15] and Zanen [14], millennial values the direct support and guidance from superiors. Lack of guidance and supervision can lead to dissatisfaction at work, and consequently increasing workers turnover intention.

Furthermore, based on the interviews with hospital director, there is an assumption that current employee's turnover may be cause by previous employees persuasion to leave the organization. This assumption is based on the number of employees left the organization has similar educational background and has decided to move to one particular hospital. 


\section{FINDINGS}

The majority of respondents were millennial women aged 24-26 years, had a diploma and bachelor education background in healthcare, with approximate tenure of 0-2 years.

Based on observations on distribution response and interviews with hospital director and head of HR unit, several indicators of leadership variables such as development of others, guidance, and feedback providing considered ineffective. This may be due to the absence of seniority between superiors and subordinates.

Several indicators on teamwork variables are highlighted including anti-discrimination and conflict resolution. This may be due to similar background on age, education, profession, and tenure between leader and subordinate, thus may cause perception of bias, prejudice, and subjectivity.

Statistically, it was found that the leadership trait has significantly negative influence on turnover intention. However, the interaction of leadership trait and teamwork weakens the influence of leadership trait on turnover intention. This situation may be caused by same level collegial relationships thus the boundaries between superiors-subordinates become vague, meanwhile millennial value the support, guidance, feedback, from their leader.

Based on these findings, it was established that leadership competency is essential to lead a group of millennial employees who needed constant feedback and guidance from a much advance and skillful leaders.

\section{CONCLUSION}

1. Contributing factors to influence the desire to leave for millennial employees are based on individual factors and organizational factors. Individual factors include age, sex, educational background, family support, work-life balance, and personal motivation. Younger employees with fairly high educational background tend to have the desire to explore their careers elsewhere. Married employees, women especially, have role conflict as wives, mothers, and career women. Work-life balance and family support become important aspects in deciding their intention to leave the organization. In addition, many millennials have the desire to become entrepreneurs lately; this reason may inspire them to leave their organization.

Organizational factors such as guidance, skill development, and career paths influence millennial to stay or leave the organization. Millennial view their leaders as someone who can develop their talents and abilities, hence they expect a leader with abilities far superior to theirs.

2. In this particular healthcare setting, leadership traits that effective to lower millennial employees' turnover intention are informal contact and openness to new ideas.

3. Due to similar background on age, education, profession, and tenure between leader and subordinate has proven that the leadership in this particular healthcare setting is not fully effective. Therefore, constant, and continuous training and development is required.

4. Teamwork is proven to lower turnover intention. However, there are factors such antidiscrimination and conflict resolution that still needs immediate attention from the management. The management needs to reevaluate their succession program and employees' career pathway and need to approach it openly and transparently.

5. The majority of millennial employees in this hospital have similar age, sex, tenure, and education background. This is proven to become obstacle for leadership effectiveness. Therefore, the management need to reevaluate the training and development of their employees based on their characters, interests, and competency.

\section{MANAGERIAL IMPLICATION}

Human resource management needs to apply retention program to improve millennial employees' commitment. This retention program is created in the form of training and development that will be measured and evaluate periodically. The purpose of this retention program is to train and develop employees' skill and competency both professionally and individually.

Top and human resource management need to plan and apply succession program in the hospital. The current succession program is not based on transparency, therefore may cause bias and prejudice among workers. Millennial are known to be confident on their skill, and they appreciate fair challenge and competition. Therefore, management transparency during the succession process will be much appreciated; reduce bias and prejudice; eliminating antidiscrimination perception; and consequently build better teamwork.

\section{SUGGESTIONS}

1. Management is to provide the hospital with wellequipped technology and proper facility for millennial to enhance their performance and productivity.

2. Management is to form group discussion forum to gain direct and efficient feedback from and to millennial employees.

3. Management is to initiate logbook program for nurses and midwifes to measure and evaluate their skill and competency; and to find the right training and development based on the user's need. This logbook program can be implemented to other units such as pharmacy, medical record, finance, and infrastructure units.

4. Management is to initiate online and offline training and development, and also formal education advancement program for their employees.

5. Management is to introduce position rotation between units for those who are interested in learning other skill outside their competency and expertise.

6. Logbook evaluation can be used as a requirement for career pathway. Furthermore, succession program can be done in a transparent way, such as polling system or internal bidding so employees are given open and fair competition based on their skill and competency evaluation.

\section{LIMITATIONS AND FUTURE RESEARCH}

This research has been conducted in accordance with scientific procedures, but still has limitations as follow: 
1. The survey was conducted at the start of Covid19 period thus may affect the respondents' consideration during survey.

2. Previous studies cultural and socio-economic background may differ to this study. Therefore, may cause different insight and result to this study.

Future studies can examine the relations of persuasion from previous employees with turnover rate and turnover intention. In addition, further studies need to research on contribution factors of turnover intention other than leadership and teamwork. The author suggests other contributing factors to be examined as follow: the relation between social status (prestige) with the intention to search in a more prestigious workplace; entrepreneurship motivation in relation to intention to quit, and lastly the relation between workplace incivility with the intention to quit.

\section{REFERENCES}

[1] Zaheer, S., Ginsburg, L., Wong, H.J. (2019). Turnover Intention of Hospital Staff in Ontario, Canada: exploring the role of frontline supervisors, teamwork, and mindful organizing. Hum Resour Health 17, 66. https://doi.org/10.1186/s12960-019-0404-2.

[2] Voon, M.L., Lo, M.C., Ayob, N.B. (2011), The Influence of Leadership Style on Employees' Job Satisfaction In Public Sector Organization In Malaysia. International Journal of Business, Management and Social Sciences, 2(1), 24-32.

[3] Phillips, K.E. (2019). Managing Millennials: The Ultimate Handbook for Productivity, Profitability, and Professionalism. New York: Routledge.

[4] Griffeth, R.W., Hom, P.W., \& Gaertner, S. (2000). A Meta-Analysis of Antecedents and Correlates Of Employee Turnover: Update, Moderator Tests, And Research Implications For The Next Millenium. Journal of Management. 26(3): 463-488.

[5] Bawdy, E., Tarek, A., \& Bassiouny, M. (2014). Employee Engagement as A Mediator Between Transformational Leadership and Intention to Quit. Journal of Management, 12 (1).

[6] Leiter, M.P., Price, S.L., \& Spence Laschinger, H.K. (2010) Generational Differences in Distress, Attitudes and Incivility Among Nurses. Journal of Nursing Management 18, 970-980.

[7] Arsenault, P. M. (2004). Validating Generational Differences: A Legitimate Diversity And Leadership Issue. Leadership \& Organization Development Journal, 25(1/2), 124-141. doi: $10.1108 / 01437730410521813$

[8] Houghton, J.D., C.P. Neck., C. C. Manz. (2003). We Think We Can, We Think We Can, We Think We Can: The Impact of Thinking Patterns and Self-Efficacy on Work Team Sustainability. Team Performance Management: An International Journal, Vol 9, No. 1/2: 31-41.

[9] Sujansky, J.G., Ferri-Reed, J. (2009). Keeping The Millennials, Why Companies Are Losing Billions In Turnover To This GenerationAnd What To Do About It. Hoboken, NJ: John Wiley \& Sons Inc

[10] Loudenback, T. (2016). Millennials Are Rapidly Changing Today's Business Landscape-Here Are 6 Reasons For It. Business Insider. Retrieved from http://www.businessinsider.com/jason-habermillennials-best-social-entrepreneurs-2016-4

[11] Gedeon, K. (2013). Millennials Have The Highest Employee Turnover Rate, Employers Call Them Expensive. Madame Noire Business Magazine.

[12] Lancaster, L. C., \& Stillman, D. (2002). When Generations Collide. Who They Are. Why They Clash. How to Solve the Generational Puzzle at Work. New York: Collins Business.

[13] Thompson, C., \& Gregory, J. B. (2012). Managing Millennials: A Framework for Improving Attraction, Motivation, And Retention. The Psychologist-Manager Journal, 15(4), 237246. doi: 10.1080/10887156.2012.730444.

[14] Zanen, D. (2018). Effective Leadership Attributes for Managing Millennials: A Dual-Perspective Approach. Tilburg University.

[15] Schaefer, C.D. (2017). Factors Contributing to Millenial Turnover Rates in Department of Defense (DOD) Organizations. Dissertation Submitted To The Bisk College of Business at Florida Institute of Technology.
[16] Mobley, W. (1982). Employee Turnover, Causes, Consequences, and Control: Addison-Wesley.

[17] Osatuke, K., Moore, S.C., Ward, C., Dyrenforth, S.R., \& Belton, L. (2009). Civility, Respect, Engagement in the Workforce (CREW) Nationwide Organization Development Intervention at Veterans Health Administration. The Journal of Applied Behavioral Science Volume 45 Number 3 September 2009 p.384-410. Doi $10.1177 / 0021886309335067$

[18] Abate, J., Schaefer, T., \& Pavone, T. (2018). Understanding Generational Identity, Job Burnout, Job Satisfaction, Job Tenure And Turnover Intention. Journal of Organizational Culture, Communications and Conflict, 22(1), 1-12. Retrieved from https://www.abacademies.org/journals/journal-of-organizationalculturecommunications-and-conflict-home.html

[19] Asiedu, G., Kumedzro, L., Aminu, S., \& Boso, N. (2017). Linking Transformational Leadership To Turnover Intention In The Public Sector. African Journal of Economic and Management Studies, 8 , 314-337. doi:10.1108/AJEMS-07-2016-0099

[20] Smith, T., \& Nichols, T. (2015). Understanding The Millennial Generation. The Journal of Business Diversity, 15(1), 39-47. Retrieved from http://www.nabusinesspress. com/jbdopen.html

[21] Wells, J., \& Peachey, J. (2011), Turnover Intentions: Do Leadership Behaviors And Satisfaction With The Leader Matter? Team Performance Management Journal, 17(1/2), 23-40. doi:10.1108/13527591111114693

[22] Nurcahyanto, D., Rofiaty., \& Rahaya, M. (2018). Paternalistic Leadership on Gen-Y Employees' Turnover Intentions with Motivation And Satisfaction As A Mediator. Journal of Applied Management (JAM) Volume 16 Number 4, December 2018. DOI: http://dx.doi.org/ 10.21776/ub.jam.2018. 016.04.08.

[23] Suhail, S., \& Zafar, O. (2013). Employee. Turnover Model. International SAMANM Journal of Marketing and Management July 2013, Vol. 1, No.2, 2308-2399.

[24] Yuniasanti, R., Abas, N., Hamzah, H. (2019). Employee turnover intention among Millennials: The Role of Psychological Well-Being and Experienced Workplace Incivility. Humanitas Indonesian Psychological Journal Vol. 16, No. 1, August 2019, 74-85.

[25] Nelsey, L., \& Brownie, (2012). Effective Leadership, Teamwork and Mentoring - Essential Elements in Promoting Generational Cohesion In The Nursing Workforce And Retaining Nurses. Collegian (Royal College of Nursing, Australia). 19. 197-202. 10.1016/j.colegn.2012.03.002.

[26] Rafferty, A.M., Ball, J., Aiken, L.H. (2001). Are Teamwork And Professional Autonomy Compatible, And Do They Result In Improved Hospital Care?. Qual Health Care. 2001;10(4):32-36.

[27] Pinel, E., \& Paulin, N. (2005). Stigma Consciousness at Work. Basic and Applied Social Psychology, 27, 345-352.

[28] Abdillah, F. (2012). Hubungan Kohevitas Kelompok Dengan Intensi Turnover Pada Karyawan. Journal of Social and Industrial Psychology.1(2), h:52-58.

[29] Aksel, I. (2008). Liderlik Teorileri. In C. Serinkan, Liderlik ve Motivasyon (pp. 33-61). Ankara: Nobel Akademik Yayincilik.

[30] Alimudin, A., \& Sukoco, A. (2017). The Leadership Style Model That Builds Work Behavior Through Organizational Culture. JURNAL LENTERA: Kajian Keagamaan, Keilmuan Dan Teknologi, 3(2),362375.

[31] Alimudin, A., Septian, D., Sasono, A. D., \& Wulandari, A. (2017). Effect of Spiritual Leadership to Organizational Culture and Employee's Loyalty. Jurnal Terapan Manajemen Dan Bisnis, 3(2), 76-86.

[32] Apker, J., Propp, K. M., \& Ford, W.S. (2009). Investigating the Effect of Nurse-Team Communication On Nurse Turnover: Relationships Among Communication, Identification, And Intent To Leave. Health Commun.2009;24(2):106-114. doi:10.1080/10410230802676508.

[33] Bass, B. M. (1997). Does The Transactional-Transformational Leadership Paradigm Transcend Organizational And National Boundaries?. American Psychologist, 52, 130. doi: 10.1037/0003066X.52.2.130.

[34] Bass, B. M., \& Bass, R. (2009). The Bass Handbook of Leadership: Theory, Research, And Managerial Applications. New York: Simon and Schuster.

[35] Bass, B. M., Avolio, B. J., Jung, D. I., \& Berson, Y. (2003). Predicting Unit Performance by Assessing Transformational and Transactional Leadership. Journal of Applied Psychology, 88, 207218. doi: 10.1037/0021-9010.88.2.207.

[36] Bawdy, E., Tarek, A., \& Manal, B. (2014). Employee Engagement as A Mediator Between Transformational Leadership and Intention to Quit. Journal of Management, 12 (1). 
[37] Bencsik, A., Csikos, G., \& Juhaz, T. (2016). Y and Z Generations at Workplaces. Journal of Competitiveness, 8(3), 90-106. https://doi.org/10.7441/joc.2016.03.06.

[38] Bencsik, A., \& Machova, R. (2016). Knowledge Sharing Problems from The Viewpoint of Intergeneration Management. In ICMLG2016 - 4th International Conferenceon Management, Leadership and Governance: ICMLG2016 (p.42). Academic Conferences and publishing limited.

[39] Buchholz, S., \& Roth, S. (2000). Creating the High Performance Team. New Jersey. Wiley.

[40] Caspi, A., \& Roberts, B. W. (2001). Personality Development Across the Life Course: The Argument For Change And Continuity. Psychological Inquiry, 12(2), 49-66. doi:10.1207/S15327965PLI1202_01.

[41] Caspi, A., Roberts, B. W., \& Shiner, R. L. (2005). Personality Development: Stability and Shange. Annual Review of Psychology, 56, 453-484.doi:10.1146/annurev.psych.55.090 902.141913.

[42] De Cremer, D. (2006). Affective and Motivational Consequences Of Leader Self-Sacrifice: The Moderating Effect Of Autocratic Leadership. The Leadership Quarterly, 17, 79-93. doi:10.1016/j.leaqua.2005.10.005.

[43] Dencker, J. C., Joshi, A., \& Martocchio, J. J. (2008). Towards A Theoretical Framework Linking Generational Memories to Workplace Attitudes And Behaviors. Human Resource Management Review, 18(3), 180-187. doi:10.1016/j.hrmr.2008.07.007.

[44] Dill, K. (2015). 7 Things Employers Should Know About the Gen Z Workforce, Forbes Magazine, 11.6. Retrieved March 16, 2016, from http://www.forbes.com/sites/Kathryn dill/2015/11/06/7 thingsemployers-shouldknow-about-the-gen-z-workforce/print/.

[45] Duffield C, Roche M, O'Brien-Pallas L, Catling-Paull C, King M. (2009). Staff Satisfaction and Retention and The Role of The Nursing Unit Manager. Collegian. 2009; 16(1): 11-17. doi:10.1016/j.colegn.2008.12.004.

[46] Eagly, A. H., Johannesen-Schmidt, M. C., \& Van Engen, M. L. (2003). Transformational, Transactional, and Laissez-Faire Leadership Styles: A Mmeta-analysis Comparing Women and Men. Psychological bulletin, 129, 569. doi: 10.1037/0033-2909.129.4.569.

[47] Elmore, T. (2014). How Generation Z Differs from Generation Y. Retrieved July 01, 2015, from http://growingleaders.com/blog/generation-z-differs-generation-y/.

[48] Estryn-Béhar, M., Van der Heijden, B.I., \& Ogińska, H. (2007). The Impact of Social Work Environment, Teamwork Characteristics, Burnout, And Personal Factors Upon Intent to Leave Among European Nurses. Med Care. 2007;45(10):939-950. doi:10.1097/MLR.0b013e31806728d8.

[49] Ferdinand. (2006). Metode Penelitian Manajemen. Semarang: Badan. Penerbit Universitas Diponegoro.

[50] Flippo, E.B. (1984). Personnel Management. New York: McGrawHill.

[51] Gastil, J. (1994). A Definition and Illustration of Democratic Leadership. Human Relations, 47, 953-975. doi: 10.1177/ 001872679404700805

[52] Gormley, D.K. (2011). Are We on The Same Page? Staff Nurse and Manager Perceptions of Work Environment, Quality of Care And Anticipated Nurse Turnover. J Nurs Manag. 2011;19(1):33-40. doi:10.1111/j.1365-2834.2010.01163.x.

[53] Hosmer, D.W. \& Lemeshow, S. (2000). Edition. New York: John Wiley and Sons, Inc.

[54] Howe, N., \& Strauss, W. (1991). Generations: the history of America's future 1584 to 2069.

[55] Howe, N., \& Strauss, W. (2000). Millennials rising: The next great generation. New York: Vintage.

[56] Hobart, B., Sendek, H. (2014). Gen Y Now: Millennials and the Evolution of Leadership. John Wiley \& Son.

[57] Hughes, R. L., Ginnett, R. C and Curphy, G. J. (2012). Leadership: Memperkaya Pelajaran dari Pengalaman, Edisi Ketujuh, Jakarta: Salemba Humanika.

[58] Hunt, J. G. (1999). Transformational / Charismatic Leadership's Transformation of The Field: An Historical Essay. The Leadership Quarterly, 10, 129-144. doi: 10.1016/S1048-9843(99)00015-6.

[59] Jurkiewicz, C. L. (2000). Generation X and the Public Employee. Public Personnel Management, 29(1), 55 https://doi.org/10.1177/009102600002900105

[60] Kalisch, B.J., \& Begeny, S.M. (2005). Improving Nursing Unit

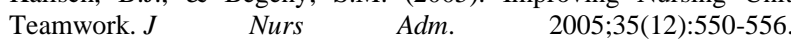
doi:10.1097/00005110-200512000-00009

[61] Kerrin, M., \& Oliver, N. (2002). Collective and Individual Improvement Activities: The Role Of Rewards Systems. Personnel Review Vol.31 No 3:335.
[62] Krishnan, H.A. (2009). What Causes Turnover Among Women on Top Management Teams. Journal of Business Research 62 (pp.1181 1186).

[63] Komariah. (2005). Visionary Leadership Menuju Sekolah Efektif. Bumi Aksara, Jakarta.

[64] Kurniawan, H., \& Alimudin, A. (2015). Pengaruh Kepuasan Kerja, Motivasi Kerja dan Kedisiplinan Terhadap Kinerja Karyawan PT. Garam (Persero). Ilmu Manajemen Magistra, 1(2).

[65] Lewin, K., Lippitt, R., \& White, R.K. (1999). Patterns of Aggressive Behaviour In Experimentally Created 'Social Climates'. In M. Gold (Ed.), The Complete Social Scientist: A Kurt Lewin Reader (pp. 227 250). Washington, DC: American Psychological Association.

[66] Lyons, S. (2004). An Exploration of Generational Values in Life and At Work. Proquest Dissertations and Theses, 441-441. Retrieved fromhttp://ezproxy.um.edu.my/docview/305203456?accountid=28930

[67] Mannheim, K. (1952). The Problem of Generations. Essays on the Sociology of Knowledge, 24(19), 276-322-24.

[68] Martin, C. A., \& Tulgan, B. (2002). Managing the Generational Mix Amherst, MA: HRD Press.

[69] Mathis, R. L., \& Jackson, J. H. (2011). Human Resource Management: Essential Perspectives. Cincinnati, Ohio: SouthWestern College Pub.

[70] Michalek, F., \& Long, M. (2013). Cohabitation with Millennials in The Workplace: A Contemporary Challenge of Leadership. Retrieved from: smash/get/diva2:631456/FULLTEXT01.pdf.

[71] Noble, S. M., \& Schewe, C. D. (2003). Cohort Segmentation: An Exploration of Its Validity. Journal of Business Research, 56(12) 979-987. doi:10.1016/S0148-2963(02)00268-0.

[72] Oblinger, D., \& Oblinger, J., Eds. (2005). Educating the Net Gen. Washington, D.C.: EDUCAUSE.

[73] Parry, E., \& Urwin, P. (2010). Generational Differences in Work Values: A Review of Theory and Evidence. International Journal of Management Reviews, 13, 79-96. doi:10.1111/j.14682370.2010.00285.x.

[74] Parsons, C. K., Herold, D. M., \& Leatherwood, M. L. (1985) Turnover During Initial Employment: A Longitudinal Study of The Role of Causal Attributions. Journal of Applied Psychology, 70(2), 337-341.

[75] Pearce, C. L., \& Sims Jr, H. P. (2002). Vertical Versus Shared Leadership as Predictors of The Effectiveness Of Change Management Teams: An Examination Of Aversive, Directive, Transactional, Transformational, And Empowering Leader Behaviors Group dynamics: Theory, research, and practice, 6, 172-197. doi:10.1037/1089-2699.6.2.172.

[76] Pio, E. A. (2015). Pengaruh Gaya Kepemimpinan Visioner, Kompensasi Tidak Langsung Dan Penempatan Kerja Terhadap Kinerja Pegawai Di Sekretariat Daerah Kabupaten Minahasa Tenggara. Volume 3, pp. 1140-1150.

[77] Raup, G.H. (2008) The Impact of ED Nurse Manager Leadership Style on Staff Nurse Turnover and Patient Satisfaction in Academic Health Center Hospitals. J Emerg Nurs. 2008;34(5):403-409. doi: 10.1016/j.jen.2007.08.020

[78] Ryder, N. B. (1965). The Cohort as a Concept in the Study of Social Change. American Sociological Review, 30(6), 843-861. https://doi.org/10.2307/2090964.

[79] Sandra, D. (2007) Teamwork - Cara Menyenangkan Membangun Tim Impian. Bandung: Proggressio.

[80] Skogstad, A., Einarsen, S., Torsheim, T., Aasland, M. S., \& Hetland, H. (2007). The Destructiveness of Laissez-Faire Leadership Behavior. Journal of occupational health psychology, 12, 80-92. doi: 10.1037/1076-8998.12.1.80.

[81] Solimun, Fernandes, A.A.R, \& Nurjannah. (2017). Metode Statistika Multivariat Permodelan Peramaan Struktural (SEM) - Pendekatan WarpPLS. Malang: UB Press.

[82] Steel, R. P., \& Ovalle, N. K. (1984). A Review and Metanalysis of Research on The Relationship Between Behavioral Intentions and Employee Turnover. Journal of Applied Psychology 69 (4):673-686.

[83] Stone, A. G., Russell, R. F., \& Patterson, K. (2004). Transformational Versus Servant Leadership: A Difference in Leader Focus. Leadership \& Organization Development Journal, 25, 349-361. doi: 10.1108/01437730410538671.

[84] Strauss, W., \& Howe, N. (1991). Generations: The History of America's Future, 1584 to 2069. New York: William Morrow \& Co.

[85] Twenge, J. M. (2006). Generation Me: Why Today's Young Americans Are More Confident, Assertive, Entitled-and More Miserable Than Ever Before. New York: Free Press.

[86] Van Eeden, R., Cilliers, F., \& Van Deventer, V. (2008). Leadership Styles and Associated Personality Traits: Support for The Conceptualization of Transactional and Transformational Leadership. 
South African Journal of Psychology, 38, 253-267. doi $10.1177 / 008124630803800201$.

[87] Yukl, G. (2013). Leadership in Organizations - Global $8^{\text {th }}$ Edition. Essex:Pearson.

[88] Zemke, R., Raines, C., \& Filipczak, B. (2000). Generations at Work: Managing the Clash of Veterans, Boomers, Xers, and Nexters in Your Workplace. New York: American Management Association. 